\title{
EPIDURAL ANALGESIA IN MULTIPY INJURED PATIENTS WITH SEVERE CHEST TRAUMA: TWO CASE REPORTS AND LITERATURE REVIEW
}

\author{
Nina Sulen ${ }^{1}$, Tatjana Šimurina ${ }^{1,2,3}$, Edi Karuc $^{1}$, Anela Tolic ${ }^{4}$ \\ ${ }^{1}$ Department of Anesthesiology, Resuscitation and Intensive Care Medicine, General Hospital Zadar, \\ Zadar, Croatia; ${ }^{2}$ Department of Anesthesiology, Resuscitation, Intensive Medicine and Pain Management, \\ Faculty of Medicine „Josip Juraj Strossmayer" University, Osijek, Croatia; \\ ${ }^{3}$ Department of Health Studies, University of Zadar, Zadar, Croatia; \\ ${ }^{4}$ Department of Radiology, General Hospital Zadar, Zadar, Croatia
}

\begin{abstract}
SUMMARY - Multiply injured patients with severe chest trauma have different combinations of associated extra thoracic injuries making their treatment complex. Severe pain is a prominent symptom in a vast majority of severe chest injuries and causes deterioration of respiratory function. Epidural analgesia provides efficient pain relief but its use in this group of patients is burdened with complications, contraindications and technical difficulties. We present two cases in which epidural analgesia was successfully used in polytrauma patients with severe chest injuries and hypoxemic respiratory failure, and discuss advantages, possible pitfalls and complications
\end{abstract}

Key words: epidural analgesia, thoracic injuries, multiple trauma, respiratory insufficiency

\section{Introduction}

Severe chest injuries are responsible for $25 \%$ of all trauma deaths, and in $25 \%$ are a contributing cause of mortality. Multiply injured patients with severe chest trauma have different combinations of associated extra thoracic injuries making their treatment complex ${ }^{1,2}$. Severe pain is a prominent symptom in a vast majority of severe chest injuries. It causes deterioration of respiratory function due to splinting, inhibition of cough and retention of secretions with formation of atelectasis. Epidural analgesia provides efficient pain relief and it has been advocated as a preferred modality of pain relief in chest trauma for years. On the other hand, the use of epidural analgesia in multiply injured patients with severe chest trauma is burdened with complications, contraindications and technical difficulties. We present two cases in which epidural analgesia was suc-

Correspondence to: Nina Sulen, General Hospital Zadar, Bože Peričića 5, 23000 Zadar, Croatia

E-mail: nsulen1729@gmail.com cessfully used in polytrauma patients with severe chest injuries and hypoxemic respiratory failure and discuss advantages, possible pitfalls and complications

\section{Case report 1}

A 30-year-old previously healthy male was admitted to emergency department after car accident. $\mathrm{He}$ fell out of the car during the crash and was found lying on the ground sometime after. On arrival he was awake, disoriented, with no recollection of the event, complaining of pain in the left shoulder and chest and his body temperature was $32{ }^{\circ} \mathrm{C}$. He had laceration of the scalp in left temporal region and subtotal amputation of left auricle. Extensive subcutaneous emphysema of the face, neck, chest and abdominal wall was present. His respiratory rate was $25 / \mathrm{min}$, peripheral oxygen saturation $95 \%$ with high concentration oxygen mask and arterial blood pressure $110 / 70 \mathrm{mmHg}$. Breath sounds were diminished on the left. He had flail chest area on the left lateral chest wall. Left tho- 
racic drain was inserted. Computed tomography (CT) scan showed bilateral pneumothoraces (maximal width $4 \mathrm{~cm}$ on the left and $2 \mathrm{~cm}$ on the right), pneumomediastinum and pneumopericardium, extensive contusions of the left lung and of upper and middle lobes of the right lung, $2^{\text {nd }}$ to $12^{\text {th }}$ multifragmental left rib fractures with severe displacement of the fractured fragments of $9^{\text {th }}$ to $12^{\text {th }}$ left rib, fractures of $1^{\text {st }}, 7^{\text {th }}$ and $12^{\text {th }}$ right rib, multifragmental fracture of left clavicle and ruptured spleen with intraabdominal hemorrhage but without active contrast extravasation. Lactate level was $7.3 \mathrm{mmol} / \mathrm{L}$ at admission.

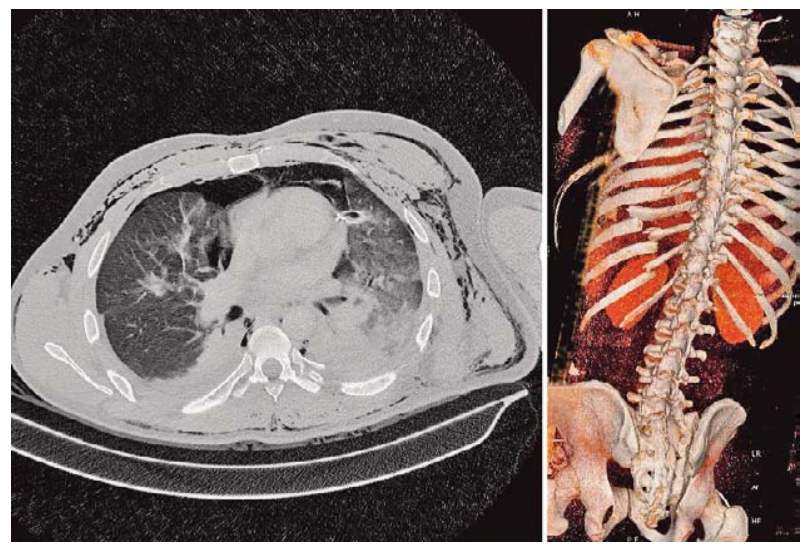

Figure 1. (LEFT) Chest CT scan showing bilateral pneumothoraces, extensive contusion of the left lung, contusion of the right lung, and massive subcutaneous emphysema (RIGHT) Three-dimensional CT reconstruction showing severe displacement of the fractured fragments of 9 th to 12 th left rib

Exploration and sutures of scalp wound and reconstruction of left auricle were performed under local anesthesia and sedation with ketamine. Analgesia was commenced with continuous infusion of sufentanil and with boluses of metamizole and paracetamol. He was hemodynamically stable and respiratory sufficient. Severe subcutaneous emphysema precluded thoracic and abdominal ultrasound examination. Control CT scan was performed the next day and revealed slight regression of pneumothorax on the left side and of subcutaneous emphysema. There was no progression of intraabdominal hemorrhage. Hemoglobin level decreased from $123 \mathrm{~g} / \mathrm{L}$ at admission to $101 \mathrm{~g} / \mathrm{L}$ and thrombocytes dropped to $99 \times 10^{9}$ Laboratory analysis showed increased creatinine of $254 \mathrm{mmol} / \mathrm{L}$ and elevated transaminase levels (AST $617 \mathrm{U} / \mathrm{L}$, ALT 495
U/L). Respiratory function deteriorated with development of hypoxemic respiratory failure (arterial blood gases $\mathrm{pO}_{2} 6.9 \mathrm{kPa}, \mathrm{pCO}_{2} 4.4 \mathrm{kPa}$ and $\left.\mathrm{pO}_{2} 87 \%\right)$. $\mathrm{Pa}-$ tient was considered a candidate for trial of noninvasive ventilatory support but it was unfeasible due to reconstruction of left auricle. Thoracic epidural catheter was placed at midthoracic level and continuous epidural analgesia commenced with a mixture of $0.1 \%$ levobupivacaine and fentanyl $2 \mathrm{mcg} / \mathrm{ml}$ at the rate of 8 $\mathrm{ml} / \mathrm{h}$. Analgesia was supplemented with intravenous boluses of pethidine and paracetamol. Inhalational therapy with salbutamol and ipratropium was started for bronchospasm and physical therapy as tolerated. In the course of the next 3 days, the patient remained hemodynamically stable but with borderline respiratory status (arterial blood gases $\mathrm{pO}_{2} 7.5-8.8 \mathrm{kPa}, \mathrm{pCO}_{2}$ 4.7-6.3 kPa, $\mathrm{SO}_{2} 89-93 \%, \mathrm{ScvO}_{2} 60-76 \%$ and lactate level $0.8-1.1 \mathrm{mmol} / \mathrm{L})$. On the $4^{\text {th }}$ day, the progression of bilateral pulmonary infiltrates was noticed on chest $\mathrm{X}$-ray with elevation of $\mathrm{C}$-reactive protein to 256.4 and procalcitonin to $4.40 \mathrm{mcg} / \mathrm{L}$. Treatment with moxifloxacin was started. Epidural catheter was removed on the $6^{\text {th }}$ day and analgesia continued with oral tramadol and ketoprofen. Patient became restless and uncooperative so sedation with continuous infusion of dexmedetomine was started. Afterwards patient showed continuous improvement of respiratory function and was eventually transferred to the ward after nine days of treatment in ICU. Osteosynthesis of the left clavicle and amputation of the left auricle were performed on $18^{\text {th }}$ day of hospitalization and patient was discharged from hospital after 20 days. Sixteen months after trauma patient reported moderate functional impairment with no chronic pain.

\section{Case report 2}

A 59-year-old male was admitted to emergency department after a fall from a height of 3 meters on a metal rod. Patient reported taking warfarin after two episodes of pulmonary embolism 4 and 6 years ago, but was otherwise in good health. On arrival he was oriented and complaining of dyspnea and pain. Extensive subcutaneous emphysema of the neck, chest and abdominal wall was present. Flail chest area on the right lateral chest wall was present with $1 \mathrm{~cm}$ wide penetrating chest wound. Air leak was audible through the chest wound. His respiratory rate was $30 / \mathrm{min}$, pe- 
ripheral oxygen saturation $90 \%$ with high concentration $\mathrm{O}_{2}$ mask and his arterial blood pressure was 90/60 $\mathrm{mmHg}$. Chest drain was placed on the right. Chest CT scan showed extensive subcutaneous emphysema, pneumomediastinum, right-sided pneumothorax, small left sided pneumothorax, laceration of the right lung, laceration of thoracic wall at the level of $6^{\text {th }}$ and $7^{\text {th }}$ right rib, $3^{\text {rd }}$ to $12^{\text {th }}$ multifragmental right rib fractures with severe displacement of fragments of $6^{\text {th }}$ to $9^{\text {th }}$ right rib. Abdominal CT scan showed a small amount of liquid below lower border of the liver, dissection of abdominal aorta extending from $2 \mathrm{~cm}$ infrarenaly to bifurcation and fractures of transverse processes of L1 and L2 bilaterally and L3 and L4 on the right. Prothrombin time at admission was 0.27 and INR 2.31.

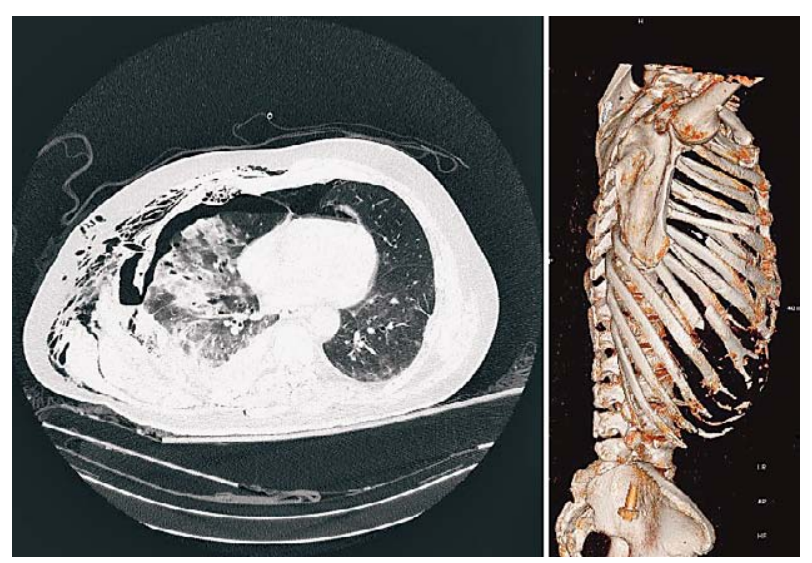

Figure 2. (LEFT) Chest CT scan showing bilateral pneumothoraces, extensive contusion of the right lung, contusion of the left lung, massive subcutaneous emphysema (RIGHT) Three-dimensional CT reconstruction showing severe displacement of fractured fragments of 6 th to 9 th right rib

Volume resuscitation with crystalloids and colloids was commenced and prothrombin complex was administered. Urgent right-sided thoracotomy was performed with middle lobe lobectomy, sutures of upper and lower lobes and reconstruction of chest wall with fixation of $7^{\text {th }}$ and $8^{\text {th }}$ rib with plates. During surgery patient received $500 \mathrm{ml}$ of packed red blood cells. Postoperatively, patient was sedated and mechanically ventilated for 3.5 hours and then extubated. Postoperative analgesia was commenced with continuous infusion of sufentanil and paracetamol. Patient remained respiratory and hemodynamically stable during the night but the following morning respiratory function significantly deteriorated. Arterial blood gasses showed hypoxemic respiratory failure $\left(\mathrm{pO}_{2} 7.05 \mathrm{kPa}, \mathrm{pCO}_{2}\right.$ $5.97 \mathrm{kPa}$ and $\mathrm{SpO} 288.7 \%$ ). Coagulation parameters were within normal limits. Epidural catheter was placed in left decubitus position. Placement of the catheter was technically difficult due to inadequate positioning of the patient and subcutaneous emphysema that precluded orientation. Attempt was made at midthoracic level, but was unsuccessful, so a catheter was placed at lower thoracic level. Epidural analgesia was started with $10 \mathrm{ml}$ bolus dose and continuous infusion of $0.1 \%$ levobupivacaine and fentanyl $2 \mathrm{mcg} / \mathrm{ml}$ at the rate of $10 \mathrm{ml} / \mathrm{h}$ with additional boluses of $3 \mathrm{ml}$. There was a significant improvement in respiratory function. Patient was transferred to the ward on the third day. Epidural catheter was removed on the fifth day. After that, analgesia consisted of a combination of oral tramadol, ketoprofen and paracetamol. Further treatment in the ward was uneventful. Patient was discharged from the hospital after 13 days. Sixteen months after the trauma patient reported mild restriction of respiratory function and no chronic pain.

\section{Discussion and literature review}

Severe chest trauma causes respiratory failure by multiple mechanisms. Pain causes hypoventilation and cough inhibition that makes the patients predisposed to developing atelectasis, retaining secretions and pneumonia. Gas exchange is impaired in injured lung and in areas of atelectasis with ventilation perfusion mismatching and development of right to left shunt. An injury to the chest wall produces altered breathing mechanics, especially in the presence of flail chest. Deterioration of respiratory function often becomes evident 24 hours and later after the injury ${ }^{3,4}$. Patients with severe thoracic trauma have significantly prolonged mechanical ventilation and ICU stay with higher rates of sepsis, respiratory and multiple organ failure ${ }^{5}$.

Effective analgesia prevents atelectasis, enables removal of pulmonary secretions and physical therapy, thus decreasing respiratory complications, mainly atelectasis and pneumonia. Opioids are efficient for alleviating static pain but are less efficient for dynamic pain and have well known side effects like respiratory depression, cough inhibition and delirium which are es- 
pecially undesirable in patients with severe chest trauma. Multimodal analgesia that includes the use of epidural analgesia or regional nerve blocks is considered the mainstay of therapy.

Use of epidural analgesia for rib fractures, when compared to opioids, demonstrated better respiratory function with reduced duration of mechanical ventilation and decreased risk of pneumonia ${ }^{6,7}$. Gage et al found in their study that epidural catheter placement significantly reduced risk of dying in patients with blunt chest injury with three or more fractured ribs ${ }^{8}$. Jensen et al demonstrated survival benefit with the use of epidural analgesia compared to alternative care in patients with rib fractures despite greater injury severity. ${ }^{9}$.

However, data from the studies are inconsistent. Meta-analysis that included eight studies and $232 \mathrm{pa}-$ tients showed that epidural analgesia did not provide mortality benefit or shortened ICU and hospital length of stay in patients with traumatic rib fractures ${ }^{10}$. In recent guideline for pain management in blunt thoracic trauma, epidural analgesia is conditionally recommended over nonregional modalities but the quality of evidence was poor. Authors noticed that if factors such as age, number of rib fractures or severity of injury are considered a stronger positive magnitude of effect may be observed for certain outcomes of interest $^{11}$. This guideline is in contrast with its older version that provided level 1 recommendation in favor of epidural over narcotic analgesia ${ }^{7}$. In formalized expert recommendations, experts recommend epidural analgesia for complex (multilevel) or bilateral injuries ${ }^{12}$.

Flail chest is defined as three of more consecutive rib fractures in two or more locations creating a flail segment. Clinical diagnosis is made when paradoxical motion of chest wall segment is observed during respiratory cycle and during coughing. It is usually accompanied with underlying pulmonary contusion and associated with higher morbidity.Use of epidural analgesia in patients with flail chest provided reduction of mortality ${ }^{3,13}$.

Optimization of analgesia with addition of epidural analgesia to multimodal regimen may obviate the need for invasive mechanical ventilation. Intubation and mechanical ventilation are undesirable and should be avoided whenever possible due to associated complications, mainly ventilator associated pneumonia, prolonged immobility, limited physiotherapy and prolongation of ICU and hospital stay. With a selection of appropriate patients non-invasive ventilation can be used successfully in trauma patients ${ }^{14}$.

Patients with severe chest trauma often present with concomitant injuries and conditions like acute traumatic coagulopathy, thoracic vertebral body fracture and spinal cord injury that are considered absolute contraindication for epidural analgesia. Bulger et al conducted a study that showed wide variability among practitioners regarding contraindications for thoracic epidural analgesia following rib fractures. The areas of greatest controversy involved minor spine injuries and minor coagulopathy. Cervical and lumbar spine fractures and traumatic brain injury are considered relative contraindications. Careful neurologic assessment must be performed before placing an epidural catheter ${ }^{15}$. Multiply injured patients often present with hypovolemia due to hemorrhage and hypotension which are also considered relative contraindications. Epidural catheters are usually placed after initial resuscitation and hemodynamic stabilization.

In severely injured patents, epidural catheter placement is often technically very challenging due to difficulties in positioning. Optimal position for epidural insertion often cannot be achieved and maintained due to pain, injuries and impaired respiratory function. This can possibly lead to increased incidence of complications related to placement of epidural catheter like dural puncture.

Patients with severe thoracic injuries are often sedated and invasively mechanically ventilated from admission. Epidural analgesia in those patients is mostly considered contraindicated due to perceived increased risk of nerve and spinal cord injury.

Efficient analgesia for thoracic wall injuries can also be achieved with paravertebral block. Injection of local anesthetic in paravertebral space produces unilateral sensory and motor block covering up to six sensory dermatomes. Reported advantages of paravertebral block in comparison to epidural analgesia include less hypotension and better mobilization ${ }^{16}$. In patients with bilateral rib fractures or if more than 6 levels are included, epidural analgesia is a preferred method of regional analgesia ${ }^{12}$. If epidural analgesia is contraindicated,a technique with two paravertebral catheters can be used. The presence of subcutaneous emphysema and hematoma hinders the use ultrasound guidance and makes insertion of paravertebral catheter technically difficult. Novel regional anesthetic tech- 
niques like serratus plane block are increasingly being used for the treatment of pain originating from chest wall but data on their efficacy is still scarce ${ }^{3}$.

In conclusion, epidural analgesia in multiply injured patients with severe thoracic trauma is underused and understudied. High quality data about the benefits and risks of epidural analgesia in this specific group of patients are lacking. Although the use of epidural analgesia is often limited in this setting with specific contraindications, technical difficulties and increased risks, in carefully selected patients it provides very efficient analgesia with awake, cooperative and spontaneously breathing patient. Careful individualized benefit risk assessment is necessary. Use of epidural analgesia for multiply injured patients with severe chest trauma requires further investigation.

Conflicts of interest: Authors have none to declare

\section{References}

1. Flagel B, Luchette F, Reed L et al. Half-a-dozen ribs: the breakpoint for mortality. Surgery 2005;138: 717-25. doi: 10.1016/j.surg.2005.07.022

2. Huber S, Biberthaler P,Delhey P et al. Predictors of poor outcomes after significant chest trauma in multiply injured patients: a retrospective analysis from the German Trauma Registry (Trauma Register DGU ${ }^{\circledR}$ ). Scandinavian Journal of Trauma, Resuscitation and Emergency Medicine. 2014, 22:52. doi: 10.1186/s13049-014-0052-4.

3. May L, Hillermann C, Patil S. Rib fracture management. BJA Education. 2016;16:26-32. https://doi.org/10.1093/bjaceaccp/ mkv011

4. Ahn Y, Gorlinger K, Alam H, Eikermann M. Case scenario: pain-associated respiratory failure in chest trauma. Anaesthesiology. 2013; 118: 701-8.

doi: 10.1097/ALN.0b013e318283996b

5. Bayer J, Lefering R, Reinhardt $\mathrm{S}$ et al. Thoracic trauma severity contributes to differences in intensive care therapy and mortality of severely injured patients: analysis based on the Trau-
maRegister DGU ${ }^{\circledR}$. World Journal of Emergency Surgery (2017) 12:43. doi: 10.1186/s13017-017-0154-1

6. Bulger EM, Edwards T, Klotz P, Jurkovich GJ. Epidural analgesia improves outcome after multiple rib fractures. Surgery. 2004;136(2):426-30. doi: 10.1016/j.surg.2004.05.019

7. Simon BJ, Cushman J, Barraco R et al. Pain management guidelines for blunt thoracic trauma. J Trauma. 2005;59:1256-67. doi: 10.1097/01.ta.0000178063.77946.f5

8. Gage A, Rivara F, Wang J, Jurkovich GJ, Arbabi S. The effect of epidural placement in patients after blunt thoracic trauma. J Trauma Acute Care Surg. 2014;76(1):39-46. doi: 10.1097/ TA.0b013e3182ab1b08.

9. Jensen CD, Stark JT, Jacobson LL et al. Improved outcomes associated with liberal use of thoracic epidural analgesia in patients with rib fractures. Pain Medicine 2017;18:1787-1794. doi: $10.1093 / \mathrm{pm} /$ pnw199.

10. Carrier FM, Turgeon AF, Nicole PC, et al. Effect of epidural analgesia in patients with traumatic rib fractures: a systematic review and meta-analysis of randomized controlled trials. Can J Anaesth. 2009;56:230-242. doi: 10.1007/s12630-009-9052-7

11. Galvagno SM Jr, Smith CE, Varon AJ et al. Pain management for blunt thoracic trauma: a joint practice management guideline from the Eastern Association for the Surgery of Trauma and Trauma Anesthesiology Society. J Trauma Acute Care Surg. 2016;81:936-51. doi:10.1097/TA.0000000000001209

12. Bouzat P, Raux M, David JS et al. Formalized expert recommendations Chest trauma: First 48 hours management. Anaesth Crit Care Pain Med 36 (2017) 135-145. doi: 10.1016/j. accpm.2017.01.003

13. Alhadhrami B, Babsail A, Elhusseini $M$ et al. Traumatic flail chest injuries and the benefits of epidural analgesia. Clin Res Trials 2017;3:1-5. doi: 10.15761/CRT.1000168

14. Karcz MK, Papadakos PJ. Noninvasive ventilation in trauma. World J Crit Care Med 2015;4:47-54. doi: 10.5492/wjccm.v4.i1.47

15. Bulger E, Edwards W, Pinto M, Klotz P, Jurkovich G. Indications and contraindications for thoracic epidural analgesia in multiply injured patients. Acute Pain 2008; 10: 15-22. doi:10.1016/j.acpain.2007.10.019

16. Malekpour M, Hashmi A, Dove J et al.Analgesic choice in management of rib fractures: Paravertebral block or epidural analgesia? Anesth Analg 2017;124:1906-11. doi: 10.1213/ ANE.0000000000002113 


\title{
Sažetak \\ PRIMJENA EPIDURALNE ANALGEZIJE \\ KOD VIŠESTRUKO OZLIJEĐENIH BOLESNIKA S TEŠKOM TRAUMOM PRSNOG KOŠA: DVA PRIKAZA SLUČAJA I PREGLED LITERATURE
}

\author{
N. Sulen, T. Šmurina, E. Karuc i A. Tolić
}

Bolesnici s teškom ozljedom prsnog koša često imaju različite pridružene ozljede drugih organskih sustava što čini njihovo liječenje vrlo kompleksnim. Bol je prominentan simptom teških ozljeda prsnog koša i neliječena doprinosi pogoršanju respiratornog statusa. Epiduralna analgezija je učinkovita metoda liječenja boli, ali je njena upotreba u ovoj skupini bolesnika često ograničena specifičnim kontraindikacijama, mogućim komplikacijama i tehničkim poteškoćama. Prikazujemo dva slučaja u kojima je uspješno primjenjena epiduralna analgezija kod politraumatiziranih bolesnika s teškom ozljedom prsnog koša i hipoksemičnim respiratornim zatajenjem.

Ključne riječi: epiduralna analgezija, ozljeda prsnog koša, multiple ozljede, respiratorno zatajenje 